1st International Conference - Global Ethics - Key of Sustainability (GEKoS) | May 15th, 2020 | Bucharest, Romania

\title{
The Efficiency of Entrepreneurial Education Programs in Romania
}

\author{
Mihaela STATE \\ https://doi.org/10.18662/lumproc/gekos2020/08
}

How to cite: State, M. (2020). The Efficiency of Entrepreneurial Education Programs in Romania. In A. Grigorescu \& V. Radu (vol. ed.), Lumen Proceedings: Vol. 11. 1st International Conference Global Ethics - Key of Sustainability (GEKoS) (pp. 65-73). Iasi, Romania: LUMEN Publishing House. https://doi.org/10.18662/lumproc/gekos2020/08 


\title{
The Efficiency of Entrepreneurial Education Programs in Romania
}

\author{
Mihaela STATE 1
}

Abstract

The evaluation of the efficiency of entrepreneurship education must be in the attention of those responsible at national level, in order to provide the necessary framework for the development of entrepreneurial skills considered one of the key competencies needed in the future. The aim of this article is to evaluate the effectiveness of entrepreneurship education programs from the perspective of students and graduates, who participated in entrepreneurship programs conducted in Romania, through the survey method. The results of the study show that there is a poor perception of the development of entrepreneurial behaviour through entrepreneurship education courses. On the other hand, the knowledge acquired in these courses is considered useful for managing a future business. The immediate results of participating in entrepreneurship education programs recognized by the participants are the accumulation of theoretical knowledge and obtaining a certificate of entrepreneurial skills. The increase of the involvement in the entrepreneurial education programs is seen by the respondents that it could be achieved by inviting some local entrepreneurs to present step by step their developed business.

Keywords: entrepreneurial education; objectives; attitude; motivation; efficiency.

\footnotetext{
1 "Ştefan cel Mare" University, Suceava, Romania, mihaela.state@,usm.ro

(c) The Authors, LUMEN Conference Center \& LUMEN Proceedings.

Selection and peer-review under responsibility of the Organizing Committee of the conference
} 


\section{Introduction}

In today's society, knowledge, innovation and entrepreneurship are the basis of economic and social development. Entrepreneurship is considered a kind of engine for a country's economic growth and a solution to the problem of unemployment.

Entrepreneurial education courses and programs have been introduced in many education systems. Studying this subject should bring students basic knowledge and interest to become potential entrepreneurs after graduation. Educational institutions in the country and abroad seek to strengthen entrepreneurship education programs to provide the context for the emergence of more young entrepreneurs in the future. Education programs are constantly revised to be consistent with requirements outside the university. Most graduates, since their student days, are thinking of finding a well-paid job in the public or private sector. They are reluctant to start their own business, feeling unprepared to face the challenges of entrepreneurship, first wanting to gain experience in a job and then become entrepreneurs.

\section{Problem Statement}

Entrepreneurial education includes: "courses, programs and pedagogical processes offered to students for the development or consolidation of entrepreneurial traits, attitudes and skills"[3]. Entrepreneurship education programs must cover „a variety of topics and themes, such as innovation, finance, team building and leadership" [9]. Entrepreneurial education integrates the knowledge, skills and experience that will allow students to successfully implement innovative ideas and be more motivated to act on them. [3].

Entrepreneurial education materializes in understanding specific key concepts, developing entrepreneurial skills and positive attitudes towards entrepreneurship [18]. Strengthening of entrepreneurial education at all educational levels will have positive effects on the dynamics and structure of entrepreneurship, increasing the number of those with higher education who choose entrepreneurship as a career [5].

Entrepreneurial learning is defined as a process by which students develop knowledge, attitudes and skills essential in business (creativity, initiative, teamwork, risk-taking and responsibility, etc.).Entrepreneurial knowledge includes understanding the stages of running a business, forming 
the specific attitudes of entrepreneurs, and developing the skills needed to capitalize on existing opportunities [14].

The impact of entrepreneurship education also depends on the individual characteristics of the target audience, on teaching methods in universities, as well as on the national context in the entrepreneurial field [13]. Exposure to additional entrepreneurship education initiatives stimulates self-reflection and makes students aware of the results obtained in entrepreneurial learning [10]. It also contributes to the increase of learning outcomes, but subsequently no longer ensures the active development of entrepreneurial knowledge; [15].

Entrepreneurship education must prepare students with the idea that failure is part of the life because entrepreneurs very often fail one or two businesses before entering the activity they are doing successfully.

In a broad sense, entrepreneurship education must develop entrepreneurial behaviour among the target audience and in a narrow sense, it must develop the ability to recognize the opportunity, capitalize on risky resources and build a business [8]. The purpose of entrepreneurship education is broader than education to start a business. Entrepreneurial education must develop the skills needed for future entrepreneurs to be able to generate new ideas and turn these ideas into viable and profitable projects [17].

Most entrepreneurship education programs have different goals. The objectives of entrepreneurship education aim at developing the entrepreneurial skills of the target audience, stimulating creativity, increasing self-confidence, encouraging innovative start-ups; awareness of the role of the entrepreneur in society and the economy. The evaluation of entrepreneurial education programs must be done in close connection with the established objectives [1].

Entrepreneurial education in universities can create a positive attitude towards entrepreneurship, promoting entrepreneurship as a respectable career for graduates [6]. Entrepreneurial education in many universities consists of developing business plans, identifying sources of funding and developing the managerial skills of future entrepreneurs. [12]. The effectiveness of entrepreneurship education programs can be achieved if universities improve their teaching methods [19]. Entrepreneurial universities can offer students the opportunity to develop new projects that generate job opportunities. Courses can be the best channel for students to become aware that they can capitalize on their knowledge and skills as potential entrepreneurs.

The short-term goals of entrepreneurship education should be: mastering the theoretical concepts specific to entrepreneurship, developing 
entrepreneurial skills and motivating students towards a career in entrepreneurship [11].The long-term results of entrepreneurship education include changing attitudes and entrepreneurial culture [2].

\section{Aims of the research}

The main challenge for teachers is to find the right combination between the structure of entrepreneurship education programs and the teaching methods that must meet university rigors, providing learning in an entrepreneurial setting [7]. Entrepreneurship requires the accumulation of knowledge and the development of which involves teaching methods capable of stimulating and providing knowledge simultaneously [16].

The existence of a close correlation between objectives, target audience, course content, teaching methods and evaluation methods is the basis of effective entrepreneurship education [1].

The question is whether entrepreneurship education in higher education has the greatest impact on entrepreneurship, given that most entrepreneurs are not college graduates, but sound entrepreneurial and managerial knowledge can best develop at this stage. The academic environment should provide a favourable framework for the development of entrepreneurial skills, the stimulation of creativity and risk management. Therefore, entrepreneurship training in universities, especially those with a technical and economic profile, is particularly important. Companies set up by young college graduates tend to be the most innovative [4].

\section{Research Methods}

The research was conducted between April and May 2020, by applying an online questionnaire and using descriptive analysis for data processing and analysis. The sample of the respondents included 165 young people with higher education or in the process of completion in Romania. The questionnaire comprises 33 items and was structured in three sections. The first section contains the socio-demographic aspects of the respondents. The second section of the questionnaire aims to assess the perception of young respondents about the effectiveness of entrepreneurship education. The third section of the questionnaire comes with proposals for improving the implementation of entrepreneurship education. 


\section{Findings}

\subsection{Structure of the sample}

The socio-demographic characteristics registered regarding the participants were: environment and country of origin, age, gender, religion, income level per family member. The average age of the participants is 23.7 years, and the origin is the urban environment for $64.5 \%$ of the respondents. Regarding religion, $87.1 \%$ are Orthodox, the rest of the participants being Catholics, Reformed, Baptists, Pentecostals, Adventists or Agnosticism. The level of net income per family member is below 1500 lei, for more than half of the participants $(51.6 \%)$. For almost a third of the participants $(32.3 \%)$, the income level per family member is between 1500 lei and 2500 lei. One of the questions in the questionnaire concerned the existence of entrepreneurs in the family. To this question, only $35.5 \%$ of respondents said they had entrepreneurs in their family.

\subsection{Perception of the beneficiaries on the efficiency of entrepreneurial education}

The attitude of the beneficiaries towards the role of entrepreneurship education is visible by expressing the agreement regarding the statement "Entrepreneurship cannot be learned in the classroom". Almost a quarter of the participants $(21 \%)$ agreed with the statement given, as can be seen in Figure 1.

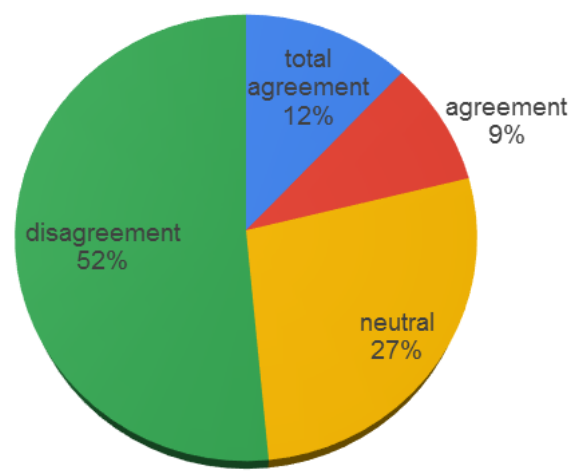

Figure 1. "The entrepreneurship cannot be learned in the classroom." 
Entrepreneurial education is considered useful for $93.9 \%$ of respondents, even if they do not intend to open their own business in the near future. The knowledge obtained through Entrepreneurial Education within the faculty is considered useful for running a business, by over $60 \%$ of the participants. At the sample level, there was no correlation between the participants' opinions with an entrepreneurial context in the family and the intention to open a business in the next period.A perspective on the perception of the beneficiaries can be had by centralizing the answers to the question regarding the main motivation for participating in entrepreneurship education courses, as it can be seen in figure 2 .

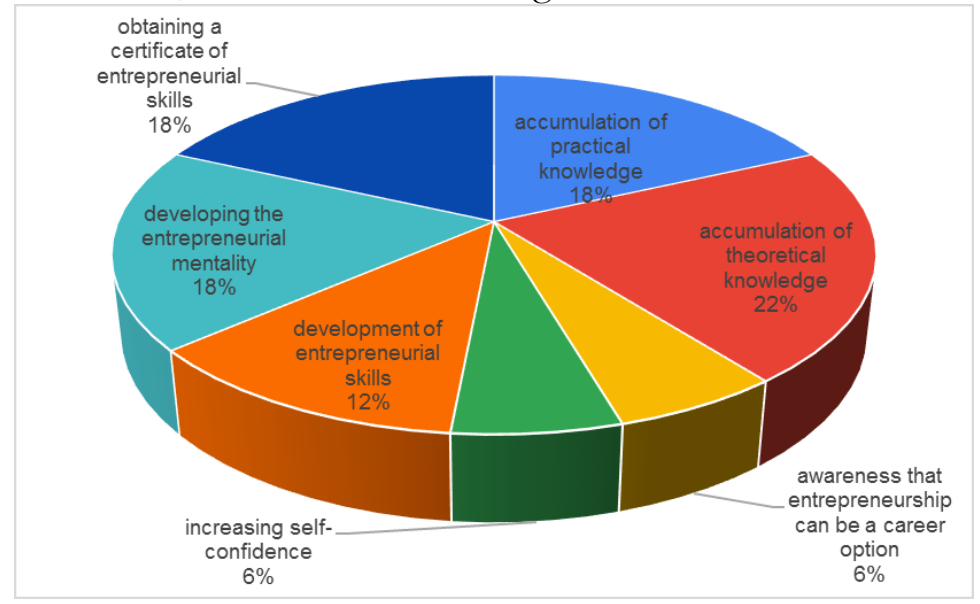

Figure 2. The main motivation for participating in entrepreneurship education

Within the entrepreneurship disciplines, $55.9 \%$ of the participants state that they have developed their entrepreneurial skills quite a lot, which will help them to better manage their future business.

According to the respondents, participation in entrepreneurship education can be stimulated by organizing competitions, inviting local entrepreneurs and the predominance of practical activities. However, entrepreneurship officials say that there are currently many projects involving students in practical activities, competitions with important prizes, including the financing of a business idea, but the interest is quite low among the participants. 


\section{Discussions}

The limits of this research are given by the relatively small sample of respondents, as well as by the short period after the completion of entrepreneurship education courses or programs. The effects of participating in entrepreneurship education courses or programs among the beneficiaries involve a longitudinal research, which should take place in the context of increasing the awareness of entrepreneurship as a possible career.

\section{Conclusions}

The analysis of a sample of 165 young people with higher education or in the process of completion allows us to discuss the implications for teachers and decision makers in the field of entrepreneurship on the nature of entrepreneurship learning, design of entrepreneurship education programs and contextual conditions, which affects the results of entrepreneurial learning. Young people have not developed their entrepreneurial attitude well enough to take the step towards an entrepreneurial career. They feel that they are not prepared enough to move from idea to action and postpone the decision after gaining experience in a job. Entrepreneurial education should focus on developing the entrepreneurial attitude among the public audience using appropriate content.

\section{Acknowledgment}

This work is supported by project POCU 125040, entitled "Development of the tertiary university education to support the economic growth - PROGRESSIO", co-financed by the European Social Fund under the Human Capital Operational Program 2014-2020

\section{References}

[1]. Alberti FG., Sciascia S, Poli A. Entrepreneurship Education: Notes on an ongoing debate.14th Annual IntEnt Conference IntEnt2004 Italy: University of Napoli Federico II; 2004.

[2]. Azizi M. The study of entrepreneurship education in public universities in Tehran and provide entrepreneurial training model. $\mathrm{PhD}$ thesis, Shahid Beheshti University; 2009.

[3]. Bae TJ, Qian S, Miao C, Fiet JO. The relationship between entrepreneurship education and entrepreneurial intentions: A meta-analytic review, Entrepreneurship Theory and Practice. 2014; 38: 217-254 
[4]. European Commission. Entrepreneurship education in higher education, especially within non-business studies. Final report of the expect group. Enterprise and Industry Directorate-General. Brussels, Belgium; 2008. Available from: https://ec.europa.eu/growth/content/final-report-expertgroup-entrepreneurship-higher-education-especially-within-non-business-0 en

[5]. European Commission. Entrepreneurship 2020 Action Plan. Reigniting the entrepreneurial spirit in Europe, Brussels, com 795 final European Commission, 2013 - Entrepreneurship Education: A Guide for Educators, Bruxelles, June 2013. Available from: https://ec.europa.eu/growth/smes/promoting-entrepreneurship/actionplan en

[6]. Galloway L, Brown W. Entrepreneurship education at university: a driver in the creation of high growth firms?,Education + Training. 2002, 44(8/9): 398405. Available from: https://doi.org/10.1108/00400910210449231

[7]. Garavan, TN, O'Cinneide B. "Entrepreneurship Education and Training Programmes: : A Review and Evaluation - Part 1", Journal of European Industrial Training. 1994; 18(8): 3-12. Available from: https://doi.org/10.1108/03090599410068024

[8]. Gibb A. In pursuit of a new 'enterprise' and 'entrepreneurship' paradigm for learning: creative destruction, new values, new ways of doing things and new combinations of knowledge. International Journal of Management Reviews. 2002; 4: 233-269. Available from: doi:10.1111/1468-2370.00086

[9]. Gielnik, Frese M, Kahara-Kawuki A et al. Action and Action-Regulation in Entrepreneurship: Evaluating a Student Training for Promoting Entrepreneurship. AMLE. 2015. 14: 69-94. Available from: https://doi.org/10.5465/amle.2012.0107

[10]. Hahn D, Minola T, Van Gils A, Huybrechts J. Entrepreneurial education and learning at universities: exploring multilevel contingencies, Entrepreneurship \& Regional Development. 2017; 29:9-10, 945-974. DOI: 10.1080/08985626.2017.1376542

[11]. Hannon PD, Scott JM, Sursani SR, Millman C. The state of education provision for enterprise and entrepreneurship: A mapping study of England's HEIs. International Journal of Entrepreneurship Education. 2006; 4:41-72.

[12]. Matlay H. Researching entrepreneurship and education: Part 2: what is entrepreneurship education and does it matter?, Education + Training.2006. 48 (8/9): 704-718. Retrieved from: https://doi.org/10.1108/00400910610710119

[13]. Mueller S, Anderson AR. Understanding the entrepreneurial learning process and its impact on students' personal development: a European perspective. International journal of management education. 2014; 12(3): 500-511. Available from: https://doi.org/10.1016/j.ijme.2014.05.003

[14]. Neck HM, Greene PG. Entrepreneurship education: Known worlds and new frontiers. Journal of Small Business Management.2011; 49:1: 55-70. DOI: 10.1111/j.1540-627X.2010.00314.x 
[15]. Parker SC. Do serial Entrepreneurs Run Successively Better-performing Businesses? Journal of Business Venturing. Elsevier. 2013; 28 (5): 652-666. DOI: $10.1016 /$ j.jbusvent.2012.08.001

[16]. Solomon G. An examination of entrepreneurship education in the United States. Journal of Small Business and Enterprise Development.2007, 14 (2): 168-182. Retrieved from: https://doi.org/10.1108/14626000710746637

[17]. Tucker D, Selcuk SS. Which factors affect entrepreneurial intention of university students?Journal of European Industrial Training. 2009; 33(2): 142 159.

[18]. Walter SG, Dohse D. Why Mode and Regional Context Matter for Entrepreneurship Education. Entrepreneurship \& Regional Development; 2012; 24 (9-10): 807-835. DOI: 10.1080/08985626.2012.721009

[19]. Zaidatol A, Lope P. Entrepreneurship as a Career Choice: An analysis of entrepreneurial self-efficacy and intention of university students. European Journal of Social Sciences. 2009; 9 (2): 338-349. 